\title{
Agronomic evaluation of corn (Zea mays L.) genotypes in the warm dry region of Chiapas, Mexico
}

Martínez-Sánchez, Jesús ${ }^{1} ;$ Espinosa-Paz, Néstor ${ }^{\dagger}$; Cadena-Iñiguez, Pedro ${ }^{1 *}$; Ariza-Flores, Rafael ${ }^{1}$; Camas-Gómez, Robertony ${ }^{1}$

Instituto Nacional de Investigaciones Forestales, Agrícolas y Pecuarias, CP 29140.

*Corresponding author: cadena.pedro@inifap.gob.mx

\section{ABSTRACT}

Objective. To evaluate the agronomic behavior of corn (Zea mays L.) experimental genotypes in three contrasting environments in the Central region of Chiapas, Mexico.

Design/methodology/approach. The experiments took place during the 2016 spring-summer agricultural cycle at Francisco Villa, Villaflores (730 m); San Luis, Suchiapa (600 m) and Ocozocoautla $(800 \mathrm{~m})$, at the Central region in the state of Chiapas, Mexico. At the three assessed sites, the climate is warm subhumid with rains in summer and intra-stival drought during the second half of July and the first half of August. The genotypes XT-5614, XT-3402, XT-5610, XT-5612, XT-5627, and BG7415W from the Biogene Company were evaluated, which are used in commercial crops at the Center of Chiapas. All genotypes showed viability greater than $90 \%$. Three experimental sites were evaluated, in a randomized complete block design with four replications. The experimental unit consisted of four $5 \mathrm{~m}$ long rows $0.8 \mathrm{~m}$ apart. The useful plot was formed by two central furrows. The evaluated variables were: days to male flowering (DMF), days to female flowering (DFF), plant height $(\mathrm{PH})$, cob height $(\mathrm{CH})$, cob length $(\mathrm{CL})$, cob diameter (CD), rows per cob (RC), grains per row and grain yield (YLD) at 14\% moisture. These were analyzed with an analysis of variance (ANOVA) and for the genotype $x$ environment interaction (GEI) the additive main effects and multiplicative interaction model (AMMI) were used, with the SAS statistical software and the GEA-R software.

Results: The combined analysis of variance detected differences between genotypes (G) for most of the variables except in grains per row. and days to male and female flowering; there were significant differences between environments (A) for all variables, while for the GEl, there were significant differences for the number of rows per cob. The CV was 1.26 (DFF) at $10 \%$ (YLD), which indicates an acceptable control (<20\%) of the experimental variability. The results indicated genetic variation between evaluated genotypes, which allows the selection of the most outstanding ones. The evaluation environments showed differential effects and this condition is necessary for the evaluation of germplasm for a genetic improvement process.

Study limitations/implications: Cob height registered acceptable values given that short plants favor rotting in hot climates when weeds are present before harvest. The flowering of the genotypes was considered acceptable and was earlier (55 d) at the Suchiapa site.

Findings/conclusions: Among the assessed genotypes there were significant differences for grain yield, plant height, cob height, cob length and the number of rows; the genotype-by-environment interaction was not significant. The XT 5627 and XT 5610 genotypes showed higher stability, and the former showed higher grain yield. The highest yields were recorded in the environment from Francisco Villa, Villaflores, at the Frailesca region, Chiapas.

Keywords: Hybrids, genotype $\times$ environment interaction, yield. 


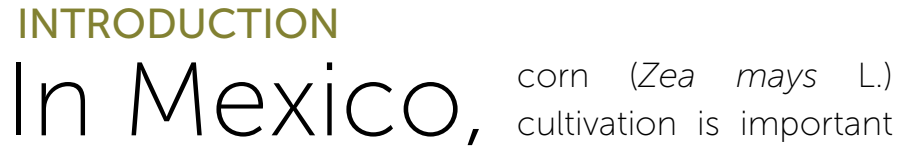
from a socioeconomic point of view because it is a basic component of the Mexican diet: 7.5 million hectares are cultivated in the country; however, only 22.1 million tons of grain are produced each year to cover food demand (Tadeo et al., 2015; SIAP, 2016). The Central Depression of the state of Chiapas, Mexico, had an altitude ranging between 600 to 800 m, with a warm dry climate and an average annual rainfall of $1000 \mathrm{~mm}$, which includes RDD 01 Tuxtla and 04 Villaflores of the Secretaría de Agricultura, Ganadería, Desarrollo Rural, Pesca y Alimentación (SAGARPA). Corn is the most important annual crop by planted area while generating an important source of employment. According to SIAP (2016), 415,000 ha are sown in this region with an average yield of $3.2 \mathrm{tha}^{-1}$. The genetic improvement programs of different companies and Public Research Centers (PRC) have their own corn germplasm, and can therefore generate genotypes of different genetic structure, such as free pollination varieties (FPV), synthetic varieties (SV), single cross hybrids $(\mathrm{SCH})$, double-cross hybrids (DCH), trilinear hybrids (TLH) and intervarietal hybrids (IVH), to achieve greater adaptation to the environment (Ramírez et al., 2015; González et al., 2016). Therefore, before recommending a genotype for planting, it is necessary to evaluate its phenotypic response to different agroecological environments. The study of the genotype-by-environment interaction (GEI) in plant genetic improvement is important since it is the result of the response of each genotype to environmental variations (Crossa and Vargas, 2000). To achieve greater progress, it is necessary to adequately establish methodologies to be used for GEl evaluation and to accurately estimate the differential response of the genotypes through environmental testing (Canales et al., 2016). Several studies have demonstrated the effectiveness of the AMMI model and the biplot graph to describe the GEl of experimental maize genotypes in multiple environments (Lozano-Ramírez et al., 2015: Sánchez-Ramirez et al., 2016); therefore, the objective was to evaluate the agronomic behavior of experimental genotypes of corn (Zea mays L.) in three contrasting environments at Chiapas Central region, Mexico.

\section{MATERIALS AND METHODS}

The experiments were established during the 2016 springsummer agricultural cycle at the towns of Francisco Villa, Villaflores (730 m); San Luis, Suchiapa (600 m) and
Ocozocoautla $(800 \mathrm{~m})$, located in the Central region of the state of Chiapas. In all three sites, the climate is warm subhumid with rains in summer and the presence of intra-estival drought during the second half of July and the first half of August.

Genetic Materials. The evaluated experimental genotypes were: XT-5614, XT-3402, XT-5610, XT-5612, XT-5627 and the commercial BG7415W genotype from the Biogene company, which is used in commercial plantings at Chiapas central region. All genotypes showed viability greater than 90\%. The genotypes were distributed in the three experimental sites, in a randomized complete block experimental design with four replications. The experimental unit consisted of four rows of $5 \times 0.8 \mathrm{~m}$, with a useful plot formed by the two central rows.

Evaluated variables. Days to male flowering (DFM), days to female flowering (DFF), plant height (AP), cob height $(\mathrm{CH})$, cob length $(\mathrm{CL})$, cob diameter (CD), rows per cob $(R C)$, grains per row and grain yield (YLD) at 14\% moisture. A combined analysis of variance (ANOVA) was performed and the additive main effects and multiplicative interaction (AMMI) model was used to evaluate the genotype-byenvironment interaction (IGA). The analysis of variance was assessed with the SAS software system (SAS, 2000) while the GEA-R program was used for the AMMI model (Pacheco et al., 2015).

\section{RESULTS AND DISCUSSION}

The combined analysis of variance detected differences between genotypes (G) for most of the variables except in grains per row and days to male and female flowering; Between environments (E) there were significant differences for all variables, for the environment $x$ genotype interaction (GEl) there were significant differences only for the number of rows per cob (Table 1). The values of the coefficient of variation (CV) ranged from 1.26 (DFF) to 10\% (YLD), which indicates an acceptable control $(<20 \%)$ of the experimental variability. The results show a genetic variation between the evaluated genotypes, which allows selecting the outstanding ones. The evaluation environments represent the agroecological conditions, where maize is grown in the Central region of Chiapas, and because they are contrasting, differential effects were shown. This condition is necessary for the germplasm evaluation process for genetic improvement (Córdoba, 1991). Table 2 presents the Gollob analysis, which allows visualizing the statistical significance of the components of the AMMI 
model. Component 1 (CP1) was statistically significant and explained $80 \%$ of the sum of squares of the genotype by environment interaction.

Table 3 presents the obtained yields in each evaluation environment. At Francisco Villa, Villaflores, Chiapas site, an average of $8,207 \mathrm{~kg} \mathrm{ha}^{-1}$ were obtained, exceeding by $39 \%$ that recorded at the Ocozocoautla and San Luis, Suchiapa sites. These results are explained because at Francisco Villa precipitation was higher and without intraestival drought. However, at San Luis and Ocozocoautla, there was a drought period (without rain) of 20 and 30 days, respectively, the drought occurred during the flowering period, at this stage, the corn plants are highly susceptible to water deficit (Márquez, 2009).

The XT 5627, XT 3402 and XT 5610 genotypes stood out from the rest with yields of 6662,6594 and $6359 \mathrm{~kg}$ $\mathrm{ha}^{-1}$ (Table 3), respectively, which exceeded the control (BG7415W) by $384 \mathrm{~kg}$ and more. Due to the length of

Table 2. Mean squares and statistical significance of the Gollob test for the components of the AMMI
multiplicative model for six evaluated genotypes of Zea mays L. in three environments. 2016 spring-
summer agricultural cycle.
\begin{tabular}{c|c|c|c|c} 
Component & Sum of squares & $\%$ Explained $^{ \pm}$ & $\%$ Accumulated & Mean Square \\
\hline CP1 & 7679624 & 80.01 & 80.01 & $1279937 * \star$ \\
\hline CP2 & 1919561 & 19.99 & 100 & 479890 NS \\
\hline
\end{tabular}

\pm Percentages with respect to the sum of squares of the genotype $\times$ environment interaction.

Table 1. Statistical significance of the combined analysis for various phenotypic characteristics of maize genotypes (Zea mays L.) in three environments. Spring-summer 2016 cycle.

\begin{tabular}{|c|c|c|c|c|c|c|c|c|c|}
\hline F.V. & $\begin{array}{l}\text { Grain } \\
\text { yield }\end{array}$ & AP & AM & DFM & DFF & LM & DM & $\mathrm{NH}$ & $\mathrm{GH}$ \\
\hline Genotipe (G) & * & ** & $\star \star$ & NS & NS & ** & NS & ** & NS \\
\hline Environment (A) & ** & $\star *$ & ** & ** & ** & ** & $* \star$ & ** & $\star \star$ \\
\hline$G \times A$ & NS & NS & NS & NS & NS & NS & NS & * & NS \\
\hline C.V. (\%) & 10.1 & 3.9 & 9.7 & 1.4 & 1.26 & 3.9 & 3.9 & 5.3 & 4.6 \\
\hline
\end{tabular}

The ${ }^{*}$ and ${ }^{* *}$ significant level at $\mathrm{P}<0.05$ and $\mathrm{P}<0.01$, respectively; N.S. $=$ Not Significant; $C . V .=$ Coefficient of variation. $\mathrm{YLD}=\mathrm{Grain}$ yield $\left(\mathrm{kg} \mathrm{ha}^{-1}\right) ; \mathrm{PH}=$ plant height $(\mathrm{m}) ; \mathrm{CH}=\mathrm{cop}$ height $(\mathrm{m})$; $\mathrm{DMF}=$ days to male flowering (DDS); $D F F=$ days to female flowering (DDS); $C L=$ Length of $c o b(\mathrm{~cm}) ; C M=C o b$ diameter $(\mathrm{cm})$; $N R=$ number of rows; $G R=$ grains per row

the cob, the XT 3202, XT 5612 and XT 5627 genotypes stood out, while the BG7415W genotype stood out due to the number of rows. These yields exceed the average of $3,200 \mathrm{~kg} \mathrm{ha}^{-1}$ reported by producers (SIAP, 2016).

Table 4 presents plant height, cob, days to male flowering and female to flowering. The evaluated genotypes presented an average plant height of 2.4 to $2.7 \mathrm{~m}$, which was not a problem since the genotypes did not present lodging; also, these values are favorable for forage production as an added value from grain yield. Regard to the cob height, the values are acceptable as short plants favor cob rotting in hot climates, especially when excess weeds are present before harvest. The flowering of the genotypes was considered acceptable and they were earlier (55 days) at the Suchiapa site, probably due to high temperatures in this locality and, also, there occurrence of intra-estival drought, compared to the other two
YLD = Grain yield $(\mathrm{kg}$ ha-1); $C L=$ Length of $\mathrm{cob}(\mathrm{cm}) ; \mathrm{DC}=$ Diameter of $\mathrm{cob}(\mathrm{cm}) ; \mathrm{NR}=$ Number of rows: $\mathrm{GR}=$ Grains per row. + Means with the same letter in a column are not statistically different. 
experimental sites. Asynchrony between male and female flowering in all genotypes was not significant.

Figure 1 shows the biplot graph that facilitates visualizing the stability of the genotypes through the environments. Yields are recorded on the " $X$ " axis and the effects of genotype-by-environment interaction (GEI) are recorded on the ordinate axis " $Y$ ". The segments represent the environments and the numbers the genotypes. The AMMI1 model was used because the first principal component explained $80 \%$ of the GEI. The biplot shows that the XT 5627 (5) and XT 5610 (3) hybrids were the closest to the origin, which indicates greater stability (Lozano-Ramírez et al., 2015; SánchezRamirez et al., 2016). The rest of the hybrids registered an acceptable performance behavior, but it considerably changes from one environment to another.

\section{CONCLUSIONS}

Among the assessed genotypes, there were significant differences for grain yield, plant height, cob, cob length and the number of rows; the genotype-by-environment interaction was not significant. The XT 5627 and XT 5610 genotypes showed higher stability and the former showed higher grain yield. The highest yields were recorded in the environment of Francisco Villa, Villaflores, in the Frailesca region, Chiapas.

\section{REFERENCES}

Canales, I.E.ı.; Tadeo, R. M.; Mejía, C. J.A.; García, Z. J.J.; Espinosa, C. A.; Castillo, G. F.; Sierra, M. M. y Gómez. M. N. 2016. Estabilidad del rendimiento de grano en híbridos trilineales androesteriles de maíz para Valles Altos de México. Revista Mexicana de Ciencias Agrícolas. 7(8): 1815-1827

Córdova, O.H.S. 1991. Estimación de parámetros de estabilidad para estimar la respuesta de híbridos de maíz (Zea mays L.) a ambientes contrastantes de Centroamérica, Panamá y México. Agronomía Mesoamericana. 2:1-10

Crossa J.; Vargas. M. 2000. El análisis AMMI y la gráfica de biplot en SAS. Unidad de biometría. CIMMYT, El Batán, México. González, M. J.; López S. A.; Estrada D. B.; Delgado, M. R.; Pecina, M. J. A.; Varela, F. E. S.; Osorio, H. E. y. Rocandio, R. M. 2016. Parámetros genéticos y heterosis en líneas derivadas de poblaciones nativas de maíz tropical de Tamaulipas. Revista Mexicana de Ciencias Agrícolas. 7(2) 387-399
Table 4. Test of means of main effects for plant height, cob height and phenology of six genotypes of corn (Zea mays L.) evaluated in three environments. 2016 spring-summer agricultural cycle.

$$
\text { Factor }
$$

$\operatorname{AP}(m)$

$\mathrm{AM}(\mathrm{m})$

DFM (dds)

DFF (dds)

Genotipe

\begin{tabular}{|l|l|l|l|l|}
\hline XT 5614 & $2.5 \mathrm{bc}^{+}$ & $1.06 \mathrm{~b}$ & $58.5 \mathrm{a}$ & $59.4 \mathrm{a}$ \\
\hline XT 3402 & $2.6 \mathrm{ab}$ & $1.10 \mathrm{ab}$ & $58.8 \mathrm{a}$ & $59.8 \mathrm{a}$ \\
\hline XT 5610 & $2.6 \mathrm{ab}$ & $1.20 \mathrm{a}$ & $59.0 \mathrm{a}$ & $60.0 \mathrm{a}$ \\
\hline XT 5612 & $2.7 \mathrm{a}$ & $1.21 \mathrm{a}$ & $58.9 \mathrm{a}$ & $59.8 \mathrm{a}$ \\
\hline XT 5627 & $2.4 \mathrm{c}$ & $1.00 \mathrm{~b}$ & $58.6 \mathrm{a}$ & $59.6 \mathrm{a}$ \\
\hline BG7415W & $2.7 \mathrm{a}$ & $1.12 \mathrm{ab}$ & $58.7 \mathrm{a}$ & $59.7 \mathrm{a}$ \\
\hline DSH & 0.14 & 0.13 & 1.0 & 0.9 \\
\hline
\end{tabular}

Environment

\begin{tabular}{|l|c|c|c|c|}
\hline Ocozocoautla & $2.6 \mathrm{a}$ & $1.2 \mathrm{a}$ & $60.3 \mathrm{a}$ & $61.3 \mathrm{a}$ \\
\hline Francisco Villa, Villa Flores & $2.6 \mathrm{a}$ & $1.1 \mathrm{~b}$ & $59.9 \mathrm{a}$ & $60.9 \mathrm{a}$ \\
\hline San Luis, Suchiapa & $2.5 \mathrm{~b}$ & $1.1 \mathrm{~b}$ & $55.2 \mathrm{~b}$ & $56.1 \mathrm{~b}$ \\
\hline DSH & 0.08 & 0.07 & 0.6 & 0.6
\end{tabular}

$\mathrm{PH}=$ Plant height $(\mathrm{m}) ; \mathrm{CH}=$ Height of $\mathrm{cob}(\mathrm{m}) ; \mathrm{DMF}=$ Days to male flowering; DFF=Days to female flowering. das=Days after sowing. ${ }^{+}$Means with the same etter in the column are not statistically different.

Lozano-Ramírez, A.; Santacruz-Varela, A.; San Vicente-García, F. Crossa, J.; Burgueño, J. y Molina-Galán, J.D. 2015. Modelación de la interacción genotipo $\times$ ambiente en rendimiento de híbridos de maíz blanco en ambientes múltiples. Rev. Fitotec. Mex. 38(4):337-347

Márquez, S. F. 2009. De las variedades criollas de maíz a los híbridos transgénicos. II. La hibridación. Agric. Soc. Des., 6(2):161- 176

\section{AMMI PCA1 Score vs rend from a RCB}

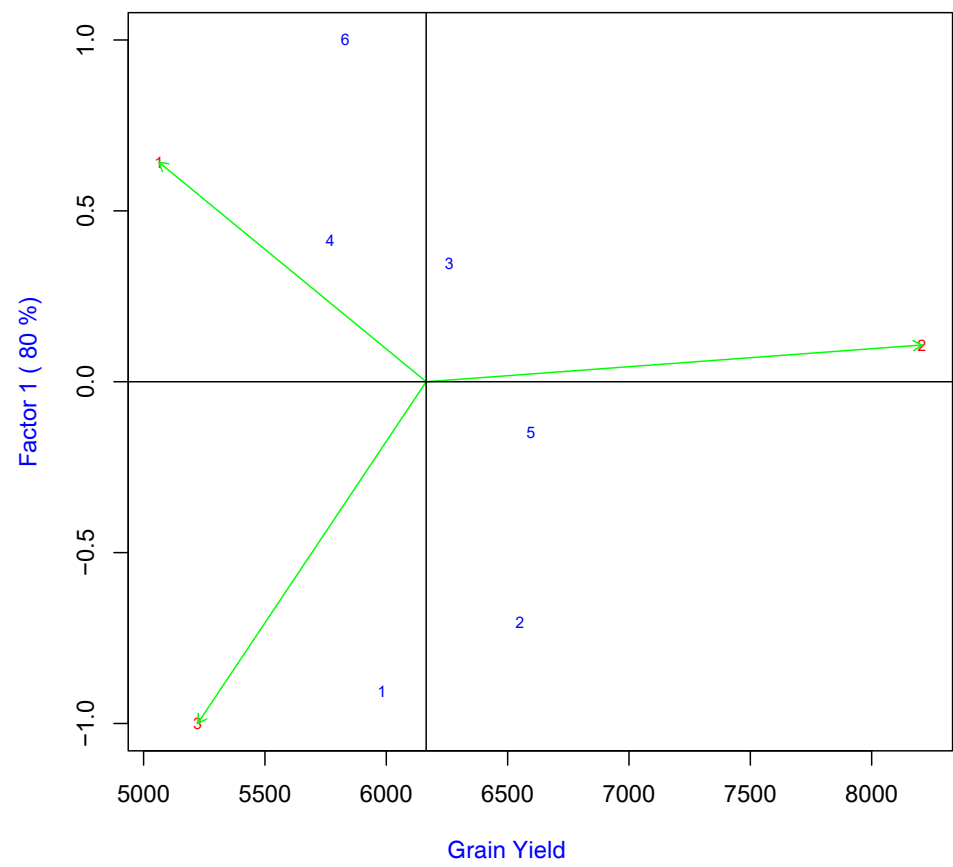

Figure 1. Biplot shows the $C P 1(G \times A)$ pattern as a function of the average yield of six maize hybrids (Zea mays L.) evaluated in three environments. 2016 spring-summer agricultural cycle. 
Pacheco, A., Vargas, M.; Alvarado, G.; Rodriguez, F.; Crossa, J. y Burgueño, J. 2015. "GEA-R Genotype × Environment Analysis with R for Windows versión 2.0", http://hdl.handle.net/11529/10203 International Maize and Wheat Improvement Center.

Ramírez, D. J. L.; Ledesma, M. A.; Vidal, M. V. A.; Gómez, M. N. O.; Ruiz, C. J. A.; Vázquez, C. G. A.; Ron, P. J.; Salinas, M. Y. y Nájera, C. L. A. 2015. Selección de maíces nativos como donadores de características agronómicas útiles en híbridos comerciales. Revista Fitotecnia Mexicana. 38(2):119-131.

Sánchez-Ramírez, F. J.; Mendoza-Castillo, M. C. y Mendoza-Mendoza, C. G. 2016. Estabilidad de cruzas simples e híbridos comerciales de maiz (Zea mays L.). Rev. Fitotec. Mex. 39(3): 269275 .

SAS Institute. 2000. Statistical Analysis System User's Guide. SAS Institute. Cary. USA. 956 p

SIAP (Servicio de Información Agroalimentaria y Pesquera). 2016. Secretaría de Agricultura, Ganadería, Desarrollo Rural, Pesca y Alimentación (SAGARPA). Cierre de producción por estado. Producción nacional de maíz grano. Disponible en: http://www.siap.gob.mx/ cierre-de-laproduccion-agricola-por-cultivo/.

Tadeo, R. M.; Espinosa, C. A.; Guzmán, M. R.; Turrent, F. A.; Zaragoza, E. J. y Virgen, V. J. 2015. Productividad de híbridos varietales de maíz de grano amarillo para Valles Altos de México. Agronomía Mesoamericana. 26(1):65-72.

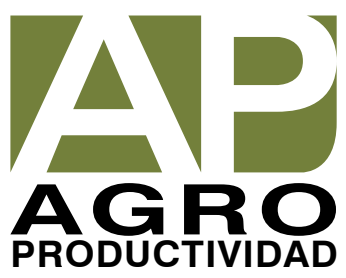

